\title{
Phytochemical Characterization and Screening of Antioxidant, Antimicrobial and Antiproliferative Properties of Allium $\times$ cornutum Clementi and Two Varieties of Allium cepa L. Peel Extracts
}

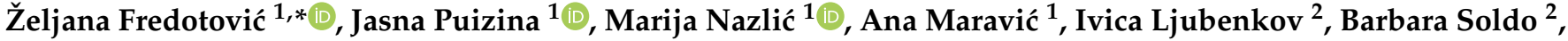 \\ Elma Vuko ${ }^{1}$ and Danica Bajić ${ }^{1}$
}

1 Department of Biology, Faculty of Science, University of Split, R. Boškovića 33, 21000 Split, Croatia; puizina@pmfst.hr (J.P.); mnazlic@pmfst.hr (M.N.); amaravic@pmfst.hr (A.M.); elma@pmfst.hr (E.V.); dbajic@pmfst.hr (D.B.)

2 Department of Chemistry, Faculty of Science, University of Split, R. Boškovića 33, 21000 Split, Croatia; iljubenk@pmfst.hr (I.L.); barbara@pmfst.hr (B.S.)

* Correspondence: zfredotov@pmfst.hr; Tel.: +38-521619292

Citation: Fredotović, Ž.; Puizina, J.; Nazlić, M.; Maravić, A.; Ljubenkov, I.; Soldo, B.; Vuko, E.; Bajić, D.

Phytochemical Characterization and Screening of Antioxidant,

Antimicrobial and Antiproliferative

Properties of Allium $\times$ cornutum

Clementi and Two Varieties of Allium cepa L. Peel Extracts. Plants 2021, 10, 832. https://doi.org/10.3390/ plants10050832

Academic Editors:

Mariangela Marrelli and

Sebastian Granica

Received: 12 March 2021

Accepted: 17 April 2021

Published: 21 April 2021

Publisher's Note: MDPI stays neutral with regard to jurisdictional claims in published maps and institutional affiliations.

Copyright: (c) 2021 by the authors Licensee MDPI, Basel, Switzerland. This article is an open access article distributed under the terms and conditions of the Creative Commons Attribution (CC BY) license (https:// creativecommons.org/licenses/by/ $4.0 /)$.

\begin{abstract}
Onions are one of the most widely grown vegetable crops. As production increases, so does the generation of waste from various parts of the onion, raising the need for efficient ecological disposal and use of such waste products. However, onion waste products are a rich source of antioxidants with a range of biological properties, therefore, they could potentially be used in food and pharmaceutical industries. In the present study, we identified the main flavonols and anthocyanins in peel extracts of Allium $\times$ cornutum Clement ex Visiani, 1842, and two varieties of Allium cepa L. and tested their antioxidant, antimicrobial and antiproliferative properties. Quercetin $3,4^{\prime}$-diglucolside, quercetin $4^{\prime}$-monoglucoside and quercetin are the most abundant flavonols in all onion extracts detected by high-performance liquid chromatography (HPLC) method. The composition of anthocyanins varied in all extracts. 2,2'-diphenyl-1-picrylhydrazyl (DPPH) and oxygen radical absorbance capacity (ORAC) assays showed that the triploid onion $A . \times$ cornutum had the highest antioxidant power. Evaluation of antimicrobial activity by broth microdilution assay also showed that $A . \times$ cornutum had higher antimicrobial activity compared to the red and yellow onion varieties. Comparable antiproliferative activity was confirmed for all onion extracts tested on three cancer cell lines: Hela (cervical cancer cell line), HCT116 (human colon cancer cell line) and U2OS (human osteosarcoma cell line). The most abundant onion flavonols (quercetin 3,4'-diglucoside and quercetin $4^{\prime}$-monoglucoside) showed weaker antimicrobial as well as antiproliferative properties compared to the extracts, leading to the conclusion that other phytochemicals besides flavonols contribute to the biological activity of onion peel extracts. The results demonstrate the antioxidant and antimicrobial properties of onion peels, which have promising potential as cancer cell proliferation inhibitors.
\end{abstract}

Keywords: Allium $\times$ cornutum Clementi ex Visiani; 1842; Allium cepa L. red and yellow variety; flavonols; anthocyanins; antioxidant properties; antimicrobial and antiproliferative activity

\section{Introduction}

Allium species, especially A. cepa (common onion), are one of the most important crops worldwide. Allium $\times$ cornutum $(2 \mathrm{n}=3 \mathrm{x}=24)$ is an established small garden crop widely distributed in southeastern Asia and Europe. Combined molecular, phylogenetic and cytogenetic analysis provided evidence for its unique genetic structure and triploid genomic origin with three putative parent species of section Cepa: A. cepa, A. roylei and the wild Asian species Allium pskemense B. Fedtsh [1]. These onions are edible species and have been used in human nutrition for years. Both production (about 105 billion pounds per 
year) and consumption have increased by over 70\% in the last twenty years. Over 500,000 tons of onion waste is generated annually in the European Union, mainly in Spain and the Netherlands. Onion peels discarded during peeling become a major environmental (rapid growth of phytopathogens) and economic problem (40€/ton disposal cost) [2]. Recently, scientists have attempted to explore the potential benefits of onion waste. It has already been shown that Allium vegetables are a source of important phytochemicals, mainly sulfur compounds and polyphenols [3-6]. However, it should be mentioned that the amount of these compounds in onion waste is significantly higher than in the edible parts of onions [7]. Until recently, flavonoids were thought to be absorbed by passive diffusion after glycosylated flavonoids were converted to aglycones following consumption of onion meal [8]. However, studies have shown that quercetin glycosides are better absorbed than quercetin aglycones in humans [9-12]. After consumption, flavonol conjugates are absorbed mainly in the stomach and/or small intestine. Flavonoids that are not absorbed in the stomach or small intestine enter the colon, where they undergo a process of deglycosylation and deconjugation and are broken down by the action of colon bacteria. Even after degradation, they influence the redox balance by stimulating the activity of antioxidant enzymes and detoxifying enzymes or leading to the formation of compounds involved in the maintenance of homeostasis [13]. Phenolic compounds show significant antioxidant, anti-inflammatory, antiallergic, antimicrobial and anticancer activity [14-22]. These properties are closely related to the structure of the most abundant phenolics, the quercetin and its conjugates $[5,15,23]$. It has been shown that the antioxidant activity of garlic and various onion varieties is significantly correlated with high total phenolic content (TPC) [24]. A previous study confirmed that the addition of onion components to the high cholesterol diet of rats reduced oxidative stress by stimulating the activity of the antioxidant system [25]. It has been reported that consumption of onions-a food rich in flavonoids-may increase the resistance of the DNA of human lymphocytes to DNA strand breaks caused by oxidative stress [26]. The strong antioxidant activity makes them one of the best antioxidants and radical scavengers that could be used not only for human nutrition, but also as a source of natural antioxidants and for pharmaceutical purposes. Several studies have shown that organosulfur compounds alone are responsible for the antimicrobial activity of onions. They successfully inhibited the growth of gram-positive bacteria belonging to the genera Bacillus, Micrococcus, Staphylococcus, Streptococcus, as well as some gram-negative bacteria such as Escherichia coli and Salmonella enteritidis [27,28]. In addition to sulfur compounds, flavonols, especially the oxidation products of quercetin present in onions, strongly inhibited the growth of Helicobacter pylori and MRSA (multidrugresistant Staphylococcus aureus) [29]. The antiproliferative activity of Allium species has been demonstrated in many in vitro and in vivo studies as well as in epidemiological studies [30-32]. This effect is related++ with both phenolic and organosulfur compounds. Quercetin glycosides (q 3,4'-diglucoside and q 4'-monoglucoside) isolated from four onions, A. chinese (Chinese onion), A. sativum (garlic), A. cepa L. (common onion) and A. fistulosum L. (Welsh onion), effectively inhibited the growth of HepG2, PC-3 and HT -29 cancer cells [33]. Therefore, the combination of quercetin glucosides might be crucial for the antiproliferative activity of onion extracts. A study by Chang et al. showed that these compounds can act as activators of apoptosis in cancer cells [34]. Flavonoids can reduce the activity of enzymes such as ornithine decarboxylase and degrade polyamines, preventing DNA synthesis and cancer cell proliferation [35-37]. Onion volatile sulfur compounds, mainly diallyl disulfides and diallyl trisulfides, play an important role in the antiproliferative activity of onions. They have been shown to reduce the growth of colon, lung and skin cancer cells and promote apoptosis in HL60, HCT-15 and neuroblastoma cells by increasing the ROS level and inducing cell death [38-42]. Epidemiological studies have shown the link between the consumption of Allium vegetables and a lower risk of developing lung, gastrointestinal, breast and brain cancer [16,43-47]. Most of these studies have been performed with edible onion bulbs, but very few studies have been conducted to evaluate the health effects of onion waste $[27,28,32,48-50]$. Considering the above-mentioned properties and beneficial 
effects on health, and the fact that the peel extracts of triploid hybrid onion $A . \times$ cornutum have never been chemically characterized or tested for their biological activity, the aim of our study is (a) to identify the compounds present in the methanolic extracts of the outer scales of two onions traditionally grown in Dalmatia $(A . \times$ cornutum and $A$. cepa $)$ and $(b)$ to investigate their antioxidant, antimicrobial and antiproliferative activities.

\section{Results and Discussion}

\subsection{Flavonol and Anthocyanin Determination by HPLC}

HPLC analysis of extracts from peel waste of triploid onion $(A . \times$ cornutum Clementi ex Visiani) and two varieties of diploid onion ( $A$. cepa L.) revealed the presence of flavonols and anthocyanins in significantly higher amounts than previously identified in onion bulb extracts [51,52]. Five different flavonols were detected in all extracts: quercetin 3, $4^{\prime}$-diglucoside (1), quercetin $4^{\prime}$-monoglucoside (2), quercetin aglycone (3), isorhamnetin (4) and kaempferol (5), as shown in the chromatograms (Figure S1). The two major flavonols identified were quercetin- $3,4^{\prime}$-diglucoside and quercetin- $4^{\prime}$-monoglucoside, the concentration of which was at least twice as high in the triploid onion $A . \times$ cornutum as in the other two diploid onion cultivars (Table 1). Compared to the results of the study with onion bulb extracts [5], the concentration of all flavonols is significantly higher in the peel extracts, almost three times higher in the peel extract of $A$. $\times$ cornutum and twice as high in the peel of the red onion variety than in its bulb extracts. Similar results, confirming the concentration of each flavonol glucoside ((1), (2) and (3)) have been reported previously [53-56]. Quercetin and its derivatives are important dominant constituents of onions. They have the role of antioxidants and free radical scavenging properties along with the ability to protect against various diseases. Considering the increased amount of these important antioxidants in onion peels as compared to onion bulbs, it would be extremely important to utilize the potential of onion peels that remain unused after processing.

Table 1. HPLC quantification of flavonols and anthocyanins in two varieties of $A$. cepa and $A . \times$ cornutum extracts.

\begin{tabular}{|c|c|c|c|}
\hline & A. $\times$ cornutum $\left(t_{\mathrm{R}}, \mathrm{min}\right)$ & $\begin{array}{c}\text { A. cepa (Yellow Variety) } \\
\left(\mathrm{t}_{\mathrm{R}}, \mathrm{min}\right)\end{array}$ & $\begin{array}{c}\text { A. cepa (Red Variety) } \\
\left(t_{R}, \min \right)\end{array}$ \\
\hline \multicolumn{4}{|l|}{ Flavonols ${ }^{a}$} \\
\hline Quercetin 3,4'-diglucoside (1) & $618.75 \pm 0.36^{\mathrm{a}}(32.52)$ & $100.40 \pm 0.05^{\mathrm{c}}(32.46)$ & $331.93 \pm 0.12^{b}(32.50)$ \\
\hline Quercetin $4^{\prime}$-monoglucoside (2) & $617.01 \pm 0.40^{\mathrm{a}}(40.47)$ & $140.43 \pm 0.10^{\mathrm{c}}(40.42)$ & $298.87 \pm 0.13^{\mathrm{b}}(40.46)$ \\
\hline Myricetin (3) & $14.88 \pm 0.01^{\mathrm{a}}(42.35)$ & $8.63 \pm 0.01^{\mathrm{c}}(42.31)$ & $9.31 \pm 0.02^{b}(42.35)$ \\
\hline Quercetin aglycone (4) & $297.21 \pm 0.40^{\mathrm{a}}(47.14)$ & $60.51 \pm 0.06^{\mathrm{c}}(47.09)$ & $70.10 \pm 0.08^{\mathrm{b}}(47.14)$ \\
\hline Isorhamnetin (5) & $32.07 \pm 0.04^{\mathrm{a}}(52.29)$ & $2.21 \pm 0.01^{\mathrm{c}}(52.23)$ & $13.73 \pm 0.01^{\mathrm{b}}(52.28)$ \\
\hline \multicolumn{4}{|l|}{ Anthocyanins ${ }^{a}$} \\
\hline Peonidin $3^{\prime}$-glucoside & $\mathrm{Nd}$ & $1.11 \pm 0.00(12.38)$ & $\mathrm{Nd}$ \\
\hline Peonidin $3^{\prime}$-glucoside acetate & $\mathrm{Nd}$ & $\mathrm{Nd}$ & $0.67 \pm 0.3(25.02)$ \\
\hline Delphinidin $3^{\prime}$-glucoside acetate & $0.23 \pm 0.00(18.71)$ & $\mathrm{Nd}$ & $\mathrm{Nd}$ \\
\hline Malvidin $3^{\prime}$-glucoside & $0.05 \pm 0.00^{\mathrm{b}}(13.44)$ & $0.53 \pm 0.00^{\mathrm{a}}(12.84)$ & $0.24 \pm 0.00^{\mathrm{b}}(13.28)$ \\
\hline Cyanidin 3'-glucoside & $0.32 \pm 0.01^{\mathrm{b}}(8.47)$ & $7.85 \pm 0.11^{\mathrm{a}}(8.56)$ & $0.11 \pm 0.00^{\mathrm{b}}(8.06)$ \\
\hline Cyanidin $3^{\prime}$-glucoside acetate & $1.22 \pm 0.01^{\mathrm{b}}(21.81)$ & $0.76 \pm 0.00^{\mathrm{c}}(22.43)$ & $3.44 \pm 0.03^{\mathrm{a}}(21.75)$ \\
\hline Petunidin $3^{\prime}$-glucoside & $\mathrm{Nd}$ & $0.12 \pm 0.00(10.58)$ & $\mathrm{Nd}$ \\
\hline Petunidin $3^{\prime}$-glucoside acetate & $\mathrm{Nd}$ & $\mathrm{Nd}$ & $0.17 \pm 0.02(23.25)$ \\
\hline
\end{tabular}

${ }^{a}$ Concentration in $\mathrm{mg} / 100 \mathrm{~g}$ dry weight; $\mathrm{t}_{\mathrm{R}}$, retention time; $\mathrm{Nd}$, not determined. Results are means $\pm \mathrm{SD}(\mathrm{n}=3)$. Different superscript letters $(\mathrm{a}, \mathrm{b}, \mathrm{c})$ indicate a statistically significant difference between three onion waste extracts $(p<0.05)$ (Data $\mathrm{S} 1)$.

The anthocyanins identified in onion waste extracts are shown in Table 1. Five anthocyanins were detected in the red and yellow varieties of $A$. cepa, while four anthocyanins were present in the extract of $A$. $\times$ cornutum. Interestingly, there are differences in anthocyanin composition in all the extracts tested. Delphinidin $3^{\prime}$-glucoside acetate was 
found only in A. $\times$ cornutum, as previously reported by Gennaro et al. [57] and Fredotović et al. [5]. Peonidin-3'-glucoside acetate and petunidin-3'-glucoside acetate were present only in the red variety of $A$. cepa, while peonidin and petunidin- $3^{\prime}$-glucoside were identified only in the yellow onion variety. The most abundant anthocyanin in all extracts was cyanidin-3-glucoside acetate and cyanidin-3-glucoside, the concentration of which was by far the highest in the yellow onion $(7.85 \pm 0.11 \mathrm{mg} / 100 \mathrm{~g}$ dry weight). Interestingly, these anthocyanins were not found in measurable amounts in the extracts of onion bulbs reported by Fredotović et al. [5]. Malvidin-3'-glucoside was also identified in all onions. The differences in anthocyanin composition and concentration are most likely due to genetic variations [58].

\subsection{Antioxidant Activity of Onion Peel Extracts}

The antioxidant activity of onion waste extracts was determined using 2,2'-diphenyl-1picrylhydrazyl (DPPH) and oxygen radical absorbance capacity (ORAC) methods. Several researchers have shown a close correlation between antioxidant capacity and phenolic content of extracts from various natural sources $[56,59,60]$. Since onion waste extracts are rich in phenolic compounds (Table 1), which are known for their ability to act as electron or hydrogen donors, they were expected to have a significant antioxidant capacity. Both Nile A. et al. [53] and Nile S.H. et al. [54] reported the antioxidant activity of the major flavonols (quercetin 3,4'-diglucoside, quercetin $4^{\prime}$-monoglucoside and quercetin aglycone) present in methanolic onion waste extracts. Pure quercetin showed the highest antioxidant capacity followed by quercetin diglucoside and then quercetin monoglucoside. The results showed that the antioxidant activity of onion extracts was correlated with phenolic content. However, the influence of organosulfur compounds on the antioxidant power of onions cannot be excluded [59,61,62]. As shown in Table 2, the extract of $A . \times$ cornutum showed significantly higher antioxidant activity than the red and yellow onion varieties in both DPPH and ORAC assays at a concentration of $100 \mu \mathrm{g} / \mathrm{mL}$, which can be explained by the higher concentration of phenolic compounds. Despite the fact that the yellow onion variety has the lowest concentration of all identified flavonols, it dominates in the amount of the anthocyanin cyanidin-3-glucoside, which has shown strong antioxidant activity due to its hydroxyl group rich structure $[58,63]$. This could explain the better DPPH and ORAC value of the yellow onion variety compared to the red variety. Škerget et al. analyzed DPPH activity for $35 \%$ acetone and $60 \%$ ethanolic extracts of yellow onion peel. They reported values of $46.95 \pm 1.02 \%$ and $47.14 \pm 1.85 \%$, respectively [28]. The antioxidant activity for yellow onion peel extract is in agreement with other results reported by Lee et al. [64]. The antioxidant DPPH activity for the ethanolic extract of yellow onion peel was $72.25 \pm 2.74 \%$ and for the water extract was $49.68 \pm 1.55 \%$. Nile et al. reported the following DPPH activity values for aqueous methanol, aqueous ethanol and ethyl acetate extracts of solid onion waste: $74.3 \pm 1.1 \%, 60.5 \pm 1.4 \%$ and $54.6 \pm 1.8 \%$, respectively [53]. Compared with the results of our previous study on onion flesh extracts [5], the present results showed that the antioxidant power increased from the inner to the outer parts of the onion. These results are consistent with those of Benítez et al. [55] and Nuutila et al. [65].

Table 2. Antioxidant potential of $A . \times$ cornutum and two varieties of $A$. cepa L. peel extracts determined by ORAC and DPPH method.

\begin{tabular}{cccc}
\hline Antioxidant Assay & A. $\times$ cornutum & $\begin{array}{c}\text { A. cepa } \text { (Yellow } \\
\text { Variety) }\end{array}$ & A. cepa (Red Variety) \\
\hline ORAC (Trolox eq) & $20.5 \pm 0.17^{\mathrm{a}}$ & $12.98 \pm 0.29^{\mathrm{b}}$ & $4.64 \pm 0.34^{\mathrm{c}}$ \\
DPPH (\% inhibition) & $82.18 \pm 1.09^{\mathrm{a}}$ & $65.76 \pm 2.97^{\mathrm{b}}$ & $53.43 \pm 4.36^{\mathrm{c}}$ \\
\hline
\end{tabular}

Results are means \pm SD $(n=3)$. Different superscript letters $(a, b, c)$ indicate a statistically significant difference between three onion waste extracts $(p<0.05)$ (Data S2). 


\subsection{Antimicrobial Activity of Extracts and Two Major Flavonols (Quercetin 3,4'-Diglucoside and Quercetin 4'-Monoglucoside)}

Many studies have highlighted the influence of organosulfur compounds in onions as important inhibitors of pathogenic bacteria growth [28,29]. However, the antimicrobial properties of phenolic compounds have also been confirmed in some studies [29,66-71]. The results of antimicrobial activity of onion waste extracts and quercetin conjugates are presented in Tables 3 and 4. All the extracts showed better inhibitory activity on gram-positive bacteria as compared to gram-negative. Similar results were obtained by Corzo-Martínez et al. [27] and Škerget et al. [28]. The extracts of $A$. $\times$ cornutum showed higher activity on all tested bacteria, yeasts and molds compared to yellow and red onion varieties. The yellow variety of $A$. cepa was more effective than the red variety. Both $A . \times$ cornutum and the yellow variety of $A$. cepa strongly inhibited the growth of the two Staphylococcus aureus strains (Clinical/MRSA and ATCC 29213) with MIC (minimum inhibitory concentration) and MBC (minimum bactericidal concentration) values: $7 \mu \mathrm{g} / \mathrm{mL}$ and $125 \mu \mathrm{g} / \mathrm{mL}$, respectively. These results are in agreement with previously reported results for onion bulb and waste extracts $[27,68,70]$. Streptococcus pyogenes (MIC $31.25 \mu \mathrm{g} / \mathrm{mL}$ ) and Listeria monocytogenes (MIC $15.6 \mu \mathrm{g} / \mathrm{mL}$ ) were more sensitive to $A . \times$ cornutum extract than Bacillus cereus (MIC $125 \mu \mathrm{g} / \mathrm{mL}$ ). Enterococcus faecalis was the least sensitive with an MIC value of $250 \mu \mathrm{g} / \mathrm{mL}$. Both A. cepa varieties showed weak or no inhibition of the growth of these bacteria. Gramnegative bacteria were significantly more resistant to all extracts. Again, A. $\times$ cornutum showed better inhibitory activity than the other two onions with an extremely high MIC value of $500 \mu \mathrm{g} / \mathrm{mL}$. A similar effect was observed by Santas et al. [68]. They showed that the ethyl acetate subfraction of crude onion extract inhibited the growth of Bacillus cereus, Staphylococcus aureus, Micrococcus luteus and Listeria monocytogenes, but had no effect on gram-negative bacteria Eschericia coli and Pseudomonas aeruginosa. No antifungal activity of A. $\times$ cornutum and A. cepa waste extracts against Candida albicans was observed, which is in agreement with previously published data [29]. Food-poisoning mold, Aspergillus niger was not affected by either the red or yellow $A$. cepa variety. $A . \times$ cornutum showed low activity against this fungus with an MIC value of $500 \mu \mathrm{g} / \mathrm{mL}$. Škerget et al. [28] investigated the antifungal activity of onion bulb and peel extracts. The authors indicated that the bulb extract showed lower efficacy in inhibiting the growth of $A$. niger than the onion peel extract. They explained this by the higher concentration of bioactive compounds in the onion peel.

Table 3. Antimicrobial activity of $A . \times$ cornutum and A. cepa (yellow and red variety) waste extracts.

\begin{tabular}{|c|c|c|c|c|c|c|c|}
\hline \multirow{2}{*}{$\begin{array}{c}\text { Species } \\
\text { Gram-Positive bacteria }\end{array}$} & \multirow[t]{2}{*}{ Strain Origin } & \multicolumn{2}{|c|}{ Allium $\times$ cornutum $^{\mathrm{a}}$} & \multicolumn{2}{|c|}{$\begin{array}{c}\text { Allium cepa (Yellow } \\
\text { Variety) }^{\text {a }}\end{array}$} & \multicolumn{2}{|c|}{$\begin{array}{c}\text { Allium cepa }(\operatorname{Red} \\
\text { Variety) }^{\text {a }}\end{array}$} \\
\hline & & MIC & MBC & MIC & MBC & MIC & MBC \\
\hline Staphylococcus aureus & ATCC 29213 & 7.8 & 125 & 7.8 & 125 & 500 & 500 \\
\hline Staphylococcus aureus & Clinical/MRSA & 31.25 & 125 & 62.5 & 125 & 500 & 500 \\
\hline Enterococcus faecalis & ATCC 29212 & 250 & 250 & 250 & 500 & 1000 & 2000 \\
\hline Streptococcus pyogenes & ATCC 19615 & 31.25 & 125 & 125 & 250 & 500 & 500 \\
\hline Listeria monocytogenes & ATCC $19111(1 / 2 a)$ & 15.6 & 125 & 250 & 500 & 1000 & 1000 \\
\hline Bacillus cereus & Food & 125 & 125 & 250 & 500 & 500 & 500 \\
\hline \multicolumn{8}{|l|}{ Gram-Negative bacteria } \\
\hline Escherichia coli & ATCC 25922 & 500 & 500 & 500 & 2000 & $>2000$ & $>2000$ \\
\hline Klebsiella pneumoniae & ATCC 13883 & 500 & 2000 & 1000 & $>2000$ & $>2000$ & $>2000$ \\
\hline Yeast & & $\mathrm{MIC}_{50}$ & $\mathrm{MIC}_{90}$ & $\mathrm{MIC}_{50}$ & $\mathrm{MIC}_{90}$ & $\mathrm{MIC}_{50}$ & $\mathrm{MIC}_{90}$ \\
\hline Candida albicans & ATCC 90029 & 10000 & 2000 & $>2000$ & $>2000$ & $>2000$ & $>2000$ \\
\hline \multicolumn{8}{|l|}{ Mould } \\
\hline Aspergillus niger & Food & 500 & 2000 & 1000 & $>2000$ & 1000 & $>2000$ \\
\hline
\end{tabular}

${ }^{\text {a }}$ Extracts of $A . \times$ cornutum and A. cepa (yellow and red variety) $(\mathrm{c}=10 \mathrm{mg} / \mathrm{mL}$ ) were tested in the final concentration range from 2000 to $1.95 \mu \mathrm{g} / \mathrm{mL}$. MIC—-minimum inhibitory concentration; MBC—-minimum bactericidal concentration. 
Table 4. Antimicrobial activity of quercetin 3,4'-diglucoside and quercetin $4^{\prime}$-monoglucoside.

\begin{tabular}{|c|c|c|c|c|c|}
\hline \multirow{2}{*}{$\begin{array}{c}\text { Species } \\
\text { Gram-Positive Bacteria }\end{array}$} & \multirow[t]{2}{*}{ Strain Origin } & \multicolumn{2}{|c|}{ Quercetin 4'-Monglucoside ${ }^{\text {b }}$} & \multicolumn{2}{|c|}{ Quercetin $3,4^{\prime}$-Diglucoside ${ }^{b}$} \\
\hline & & MIC & MBC & MIC & MBC \\
\hline Staphylococcus aureus & ATCC 29213 & $>300$ & $>300$ & $>200$ & $>200$ \\
\hline Staphylococcus aureus & Clinical/MRSA & $>300$ & $>300$ & $>200$ & $>200$ \\
\hline Enterococcus faecalis & ATCC 29212 & 150 & $>300$ & 200 & $>200$ \\
\hline Streptococcus pyogenes & ATCC 19615 & $>300$ & $>300$ & $>200$ & $>200$ \\
\hline Listeria monocytogenes & ATCC $19111(1 / 2 a)$ & $>300$ & $>300$ & $>200$ & $>200$ \\
\hline Bacillus cereus & Food & $>300$ & $>300$ & $>200$ & $>200$ \\
\hline \multicolumn{6}{|l|}{ Gram-Negative Bacteria } \\
\hline Escherichia coli & ATCC 25922 & $>300$ & $>300$ & $>200$ & $>200$ \\
\hline Klebsiella pneumoniae & ATCC 13883 & $>300$ & $>300$ & $>200$ & $>200$ \\
\hline Yeast & & $\mathrm{MIC}_{50}$ & $\mathrm{MIC}_{90}$ & $\mathrm{MIC}_{50}$ & $\mathrm{MIC}_{90}$ \\
\hline Candida albicans & ATCC 90029 & 300 & $>300$ & $>200$ & $>200$ \\
\hline \multicolumn{6}{|l|}{ Mould } \\
\hline Aspergillus niger & Food & 150 & $>300$ & 200 & $>200$ \\
\hline
\end{tabular}

${ }^{\mathrm{b}}$ Quercetin $4^{\prime}$-monoglucoside $(\mathrm{c}=1.5 \mathrm{mg} / \mathrm{mL}$ ) was tested in the concentration range of 300 to $0.3 \mu \mathrm{g} / \mathrm{mL}$, while in the case of quercetin $3,4^{\prime}$-diglucoside $(\mathrm{c}=1 \mathrm{mg} / \mathrm{mL}$ ) the concentration range was 200 to $1.9 \mu \mathrm{g} / \mathrm{mL}$. MIC—minimum inhibitory concentration, $\mathrm{MBC}$ - minimum bactericidal concentration.

As mentioned in Section 2.1., onion peel extracts are rich in glucosidic forms of phenols, mainly quercetin 3,4'-diglucoside and quercetin $4^{\prime}$-monoglucoside, which we also tested for antimicrobial activity. To our knowledge, there are no data on the antimicrobial activity of dominant quercetin conjugates of onion waste extracts. There are few studies on flavonoid glycosides, mainly flavonol 3-O-glycosides, which showed strong antibacterial activity against gram-positive bacteria and low activity against gram-negative bacteria [70].

Quercetin 3,4'-diglucoside and quercetin $4^{\prime}$-monoglucoside showed similar inhibitory effects on almost all microbes tested, except Enterococcus faecalis and Aspergillus niger, which were slightly better affected by the monoglucoside form of quercetin (Table 4). The antimicrobial activity of the pure quercetin conjugates was generally lower than that of the $A$. $\times$ cornutum extract and the yellow variety of the $A$. cepa extract, except for the Gram-negative bacteria E. coli and K. pneumoniae and the food-poisoning mold Aspergillus niger. Several studies have shown that the glycoside forms of phenols have weaker activity than phenol aglycones because they lack a hydroxyl group on the C-3 atom, which has been shown to be necessary for antimicrobial activity $[28,29,70]$. The results of the present study suggest that there are other biologically active components in onion extracts besides flavonols that are responsible for antimicrobial activity. Further research is needed to determine the synergistic effect of the bioactive components of onion extracts.

\subsection{Antiprioliferative Activity of Onion Extracts and Two Major Flavonols (Quercetin 3,4'-Diglucoside and Quercetin 4'-Monoglucoside) on HeLa, HCT116 and U2OS Cancer Cell Lines}

The antiproliferative activity of the $A . \times$ cornutum and two varieties of $A$. cepa extracts as well as the flavonols were tested against three cancer cell lines using an MTS cell proliferation assay. Cells were treated with various concentrations of onion extracts and incubated for $48 \mathrm{~h}$. Subsequently, the half maximal inhibitory concentration $\left(\mathrm{IC}_{50}\right)$ value was determined. In contrast to the results of antioxidant and antimicrobial activity, in the case of antiproliferative activity, the red variety of $A$. cepa proved to be better than the yellow variety and $A . \times$ cornutum in inhibiting the proliferation of two cancer cell lines, HCT116 and U2OS (Figure 1a). These results are in correlation with the previously reported study conducted with $A$. $\times$ cornutum and $A$. cepa bulb extracts [6]. 
a

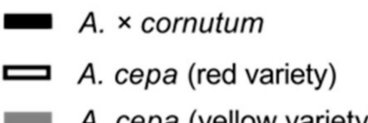

A. cepa (yellow variety)

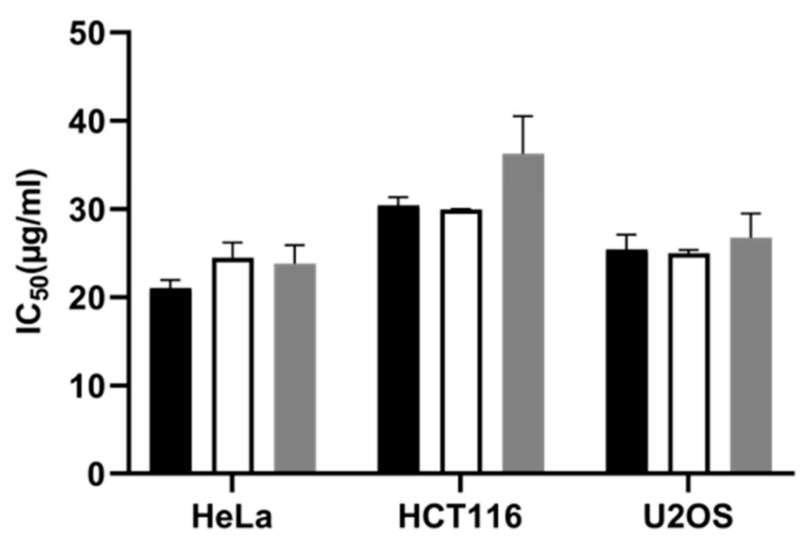

b

$$
\text { चuercetin } 4^{\prime} \text {-monoglucoside }
$$

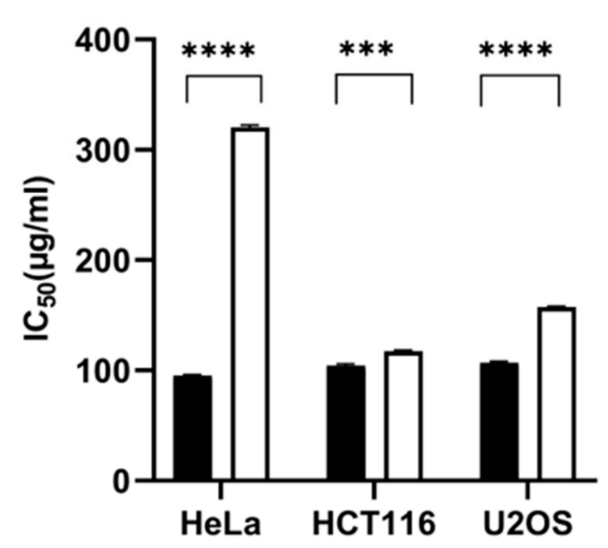

Figure 1. Antiproliferative activity of onion waste extracts (a) and quercetin conjugates (b) determined by MTS-based cell proliferation assay. The results are expressed as mean values of three independent experiments \pm SD (standard deviation). Statistically significant differences are marked with ${ }^{* * *} p<0.001$ and ${ }^{* * *} p<0.0001$ (Data S3 and S4).

A. $\times$ cornutum and yellow variety of $A$. cepa showed similar and slightly better inhibitory activity on HeLa cells than the red variety of $A$. cepa. Similar results were obtained for other Allium extracts on different cancer cell lines. Murayyan et al. [72] showed that five Ontario grown onion varieties exhibited potent antiproliferative activity against human adenocarcinoma cells (Caco-2). Kim et al. [48] confirmed the cytotoxic effect of ethanol extract of onion peel on human colon carcinoma cells (HT-29). Similar results were obtained by $\mathrm{Xu}$ et al. [73] who indicated that the watery extract of $A$. ursinum inhibited proliferation and induced apoptosis in human AGS gastric cancer cells. Nile et al. [53] showed that not only the onion solid waste (OSW) extract, but also each extracted flavonol glucoside from the OSW extract was cytotoxic to human renal carcinoma (ACHN), human pancreatic carcinoma (Panc1), human non-small lung carcinoma (Calu 1), human non-cell lung carcinoma (H460) and human colon cancer (HCT116).

The good antiproliferative activity of onions is certainly due in part to the quercetin glycosides, which have been identified as the major bioactive components of the extracts. However, it is evident that there are other biologically active molecules that also contribute to the antiproliferative activity. The present results (Figure 1b) show that the quercetin glycosides have moderate activity on the tested cancer cells compared to the extracts. Quercetin $4^{\prime}$-monoglucoside showed a lower $\mathrm{IC}_{50}$ value on all cells, indicating that it has a significantly better antiproliferative activity than the second most important quercetin glycoside present in the onion peel extracts-quercetin 3,4'-diglucoside. Previous studies have shown that the combination of quercetin glycosides may modulate the antiproliferative activity of onion extracts on various cancer cells $[33,74,75]$, They also suggested that quercetin glycosides can activate apoptosis in various cancer cell lines. Their action could also be related with their ability to inhibit prooxidant processes or the enzyme xanthine oxidase, and in this way prevent cancer proliferation $[75,76]$.

The biological activity of flavonols from Allium plants depends largely on their bioavailability. The bioavailability of quercetin and its glucoside compounds is perhaps one of the most studied, precisely because they contribute to the major intake in humans. Despite many studies, their bioavailability in the human body has not been fully elucidated. Many factors influence the site and manner in which flavonols are absorbed, and it mainly depends on their chemical structure [77]. We performed in vitro digestion of onion extracts to determine the stability of flavonols and the effect on the antiproliferative activity.

The results showed that the extracts remained quite stable after oral and gastric digestion, as we found no significant differences in antiproliferative activity compared 
to undigested extracts. This is in correlation with previous studies which confirmed that most polyphenols are relatively stable under gastric digestion [78,79]. In vitro small intestinal digestion increased the antiproliferative activity of the extracts on all cancer cells tested compared to the undigested (control) extract (Figure 2). There are numerous reports on the increased bioactivity of plant extracts after in vitro stimulated digestion. The authors generally reported increased antioxidant and antiproliferative activity [78,80-82]. In addition, they state that during digestion, compounds are transformed into those with a different chemical structure and pharmacological properties. We assume that quercetin glycosides might be transformed into different structural forms such as quercetin aglycone. Murota and Terao [83] reported that quercetin glucosides are better absorbed in the stomach than quercetin aglycone, due to their water solubility. The quercetin aglycone is relatively lipophilic, which is why it can pass the intestinal barrier more easily by passive transport, unlike the glycosides which are hydrophilic due to their structure rich in sugar moieties. An increase in quercetin amount after in vitro digestion was reported by Hur et al. [78]. They showed that the amount of quercetin in onion extract as well as its antioxidant activity increased significantly more after in vitro digestion in the small intestine than after digestion in the mouth and stomach. It seems that the reason could be the difference in $\mathrm{pH}$ or enzymes between stomach and small intestine. Other factors, such as temperature, oxygen or enzymes, may also have an influence on the phenolic composition [80-84].
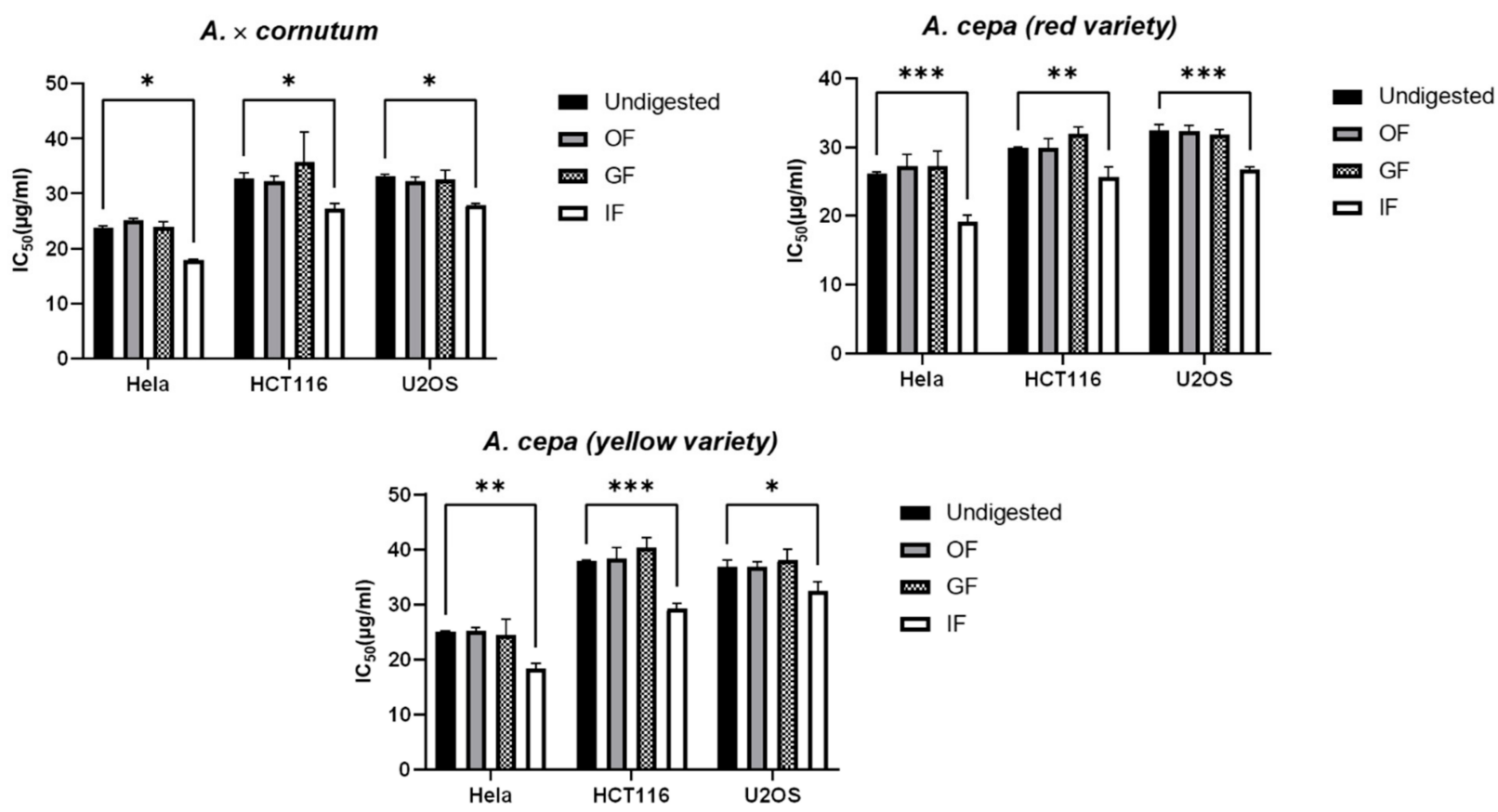

Figure 2. Antiproliferative activity of digested onion waste extracts determined by MTS-based cell proliferation assay. The results are expressed as mean values of three independent experiments \pm SD (standard deviation). Statistically significant differences are marked with ${ }^{*} p<0.05,{ }^{* *} p<0.01$ and ${ }^{* * *} p<0.001$ (Data S5-S7). Undigested-control extract, OF-oral phase, GF-gastric phase and IF-intestinal phase.

In conclusion, this study provided evidence for the possibility of using onion peel extracts as cytotoxic agents that could potentially reduce the risk of cancer development. It is necessary to conduct further in vitro and in vivo studies, both with the extracts and with individual compounds of the extracts, in addition to further bioavailability studies, in order to reveal the mechanism of action and to open up the possibility of their use as chemotherapeutic agents. 


\section{Materials and Methods}

\subsection{Collection of Plant Material and Preparation of Onion Waste Extracts}

Allium $\times$ cornutum Clementi ex Visiani (Ljutika) was obtained from local gardens along the Dalmatian coast and Allium cepa L. (Red Baron and Holandska rumena (Stuttgarter reisen) varieties) was purchased at the local market with domestic products. Outer layers of onion bulbs were separated from edible parts, washed and air-dried overnight. Then the peels were freeze-dried and homogenized with $70 \%$ methanol water. The samples were extracted three times for $30 \mathrm{~min}$ with magnetic stirring at room temperature $\left(\mathrm{ca} .20^{\circ} \mathrm{C}\right.$ ) and the homogenate was centrifuged at $3000 \mathrm{rpm}$ for $15 \mathrm{~min}$. The supernatants were pooled and the solvent was removed using a rotary evaporator (approx. $50{ }^{\circ} \mathrm{C}$ ). The procedure was repeated until a constant sample weight was obtained. The onion peel extracts were dissolved in $10 \%$ DMSO and filtered through a $0.45 \mu \mathrm{m}$ nylon filter before use.

\subsection{Phytochemical Characterization of Extracts}

Flavonols were measured by high-performance liquid chromatography (HPLC) using the Perkin Elmer HPLC system (Waltham, MA, USA), which consists of a binary pump Series 200, an autosampler, Peltier column oven Series 200, UV-VIS detector Series 200, and an UltraAqueous C18 column $(250 \times 4.6 \mathrm{~mm}$, Resek, Bellefonte, PA, USA). The TotalChrom Workstation software (version 6.2.1, Perkin Elmer, Waltham, MA, USA) was used to process the chromatographic data. Anthocyanins were analyzed using a Varian HPLC system (Varian, Inc., Harbour City, CA, USA) consisting of a Star 9010 pump, a Rheodyne 7125 syringe-charge sample injector, a 500- LC module for a column oven, a ProStar 330 photodiode array detector, and a Star Chromatography workstation, version 5 . Separation was performed using a Kinetex C18 core-shell column $(150 \times 4.6 \mathrm{~mm})$ filled with $5 \mu \mathrm{m}$ particles and equipped with a SecurityGuard ULTRA Cartridge UHPLC C18 for $4.6 \mathrm{~mm}$ ID column (Phenomenex, Torrance, CA, USA), both thermostated to $35^{\circ} \mathrm{C}$. HPLC analysis was performed according to Fredotović et al. (2017) [5]. Identification of flavonols and anthocyanins was based on their retention times compared to the standards. Quantification of each compound was determined using the calibration curves of the external standard. Quercetin, quercetin 4'-monoglucoside Sigma-Aldrich (St. Louis, MO, USA), and quercetin $3,4^{\prime}$-diglucoside (Polyphenols AS, Sandnes, Norway) prepared in methanol were used as standards for the identification of flavonols, and malvidin 3-O-glucoside chloride (Extrasynthese, Genay, France) for anthocyanins. The amount of each compound was expressed as mg/100 g dry weight. Retention time (RT), limit of detection (LOD), limit of quantification (LOQ), and coefficient of correlation (R2) for flavonols and anthocyanins are presented in Supplementary material (Data S8).

\subsection{Antioxidant Activity of Onion Peel Extracts \\ 3.3.1. Oxygen Radical Absorbance Capacity Assay (ORAC)}

The assay was performed in a Perkin-Elmer LS55 spectrofluorimeter, using 96-well white polystyrene microtiter plates (Porvair Sciences, Leatherhead, UK) according to a method described by Fredotović et al. [5]. Each reaction contained $180 \mu \mathrm{L}$ of fluorescein $(1 \mu \mathrm{M}), 70 \mu \mathrm{L}$ of 2,2'-Azobis(2-methyl-propionamidine) dihydrochloride (AAPH, Acros Organics) $(300 \mathrm{mM})$, and $30 \mu \mathrm{L}$ of plant extract or reference standard Trolox (6.25$50 \mu \mathrm{M})$ (Sigma-Aldrich). All experimental solutions were prepared in a phosphate buffer $(0.075 \mathrm{mM}, \mathrm{pH} 7.0)$. The extract was prepared in methanol $(1 \mathrm{mg} / \mathrm{mL})$ and further diluted in a phosphate buffer until the concentration was $15.6 \mu \mathrm{g} / \mathrm{mL}$. These solutions were further diluted $40 \times$ and $80 \times$ with the phosphate buffer for the experiments. Measurements were performed in triplicate. ORAC values were expressed as $\mu \mathrm{mol}$ of Trolox equivalents (TE) per $\mathrm{mL}$ of extract (for concentration $100 \mu \mathrm{g} / \mathrm{mL}$ ).

\subsubsection{Measurement of DPPH Radical Scavenging Activity}

The antioxidant capacity of the extracts was determined by the DPPH method previously used by Nazlić et al. [85]. This method uses 96 -well microtiter plates for the reduction 
reaction of alcoholic DPPH (2,2-diphenyl-1-picrylhydrazyl) solution (Sigma-Aldrich) in the presence of a hydrogen-donating antioxidant. Plant extracts as described in the ORAC method were used (methanolic onion peel extracts). After the final step of adding $100 \mu \mathrm{L}$ of a methanolic solution of DPPH $(200 \mu \mathrm{M})$ to each well, the reaction starts and the initial absorbance was immediately measured at $517 \mathrm{~nm}$, using $\mathrm{MeOH}$ as a blank. After 30 and 60 min incubation, the absorbance was measured again and the percentage of DPPH inhibition was calculated according to the following formula of Yen and Duh [86]:

$$
\% \text { inhibition }=\left(\left(\mathrm{A}_{\mathrm{C}}(0)-\mathrm{A}_{\mathrm{A}}(t)\right) / \mathrm{A}_{\mathrm{C}}(0)\right) \times 100,
$$

where $\mathrm{A}_{C}(0)$ is the absorbance of the control at $t=0 \mathrm{~min}$, and $\mathrm{A}_{\mathrm{A}}(t)$ is the absorbance of the antioxidant at $t=1 \mathrm{~h}$. All measurements were performed in triplicate.

\subsection{Antimicrobial Activity of Onion Extracts and Quercetin Conjugates \\ 3.4.1. Microbial Strains}

To assess antimicrobial activity, extracts of $A . \times$ cornutum and $A$. cepa peels, as well as quercetin 3, $4^{\prime}$-diglucoside and quercetin $4^{\prime}$-monoglucoside were tested against eleven strains of human opportunistic pathogens and food-spoilage microorganisms. The antimicrobial tests included Gram-negative Escherichia coli ATCC 25922 and Klebsiella pneumoniae ATCC 13883, and five Gram-positive species: Staphylococcus aureus (ATCC 29213 and a methicillin-resistant S. aureus clinical strain MRSA-1), Listeria monocytogenes ATCC 19111, Streptococcus pyogenes ATCC 19615, Enterococcus faecalis ATCC 29212 and food-borne Bacillus cereus isolate. The antifungal efficacy was evaluated against the opportunistic yeast Candida albicans ATCC 90029 and food-spoilage mold Aspergillus niger.

\subsubsection{Broth Microdilution Assays}

Broth microdilution assays were performed according to the European Committee on Antimicrobial Susceptibility Testing (EUCAST) protocols for bacteria (EUCAST 2020a) [87] and fungi (EUCAST 2020b, 2020c) [88,89]. Sabouraud dextrose broth (SDB; Biolife Italiana, Milano, Italy) was used for fungal growth.

All solutions were prepared in $10 \%$ DMSO. Extracts of $A . \times$ cornutum and A. cepa peels $(10 \mathrm{mg} / \mathrm{mL})$ were tested in the concentration range of 2000 to $1.95 \mu \mathrm{g} / \mathrm{mL}$. Quercetin $4^{\prime}$ monoglucoside $(1.5 \mathrm{mg} / \mathrm{mL})$ was tested at concentrations ranging from 300 to $0.3 \mu \mathrm{g} / \mathrm{mL}$, while in the case of quercetin 3, $4^{\prime}$-diglucoside $(1 \mathrm{mg} / \mathrm{mL})$ concentration ranged from 200 to $1.9 \mu \mathrm{g} / \mathrm{mL}$. The assays were performed in 96-well polystyrene microtiter plates as previously described [90]. Briefly, exponentially grown bacterial cultures in Mueller-Hinton broth (MHB; Biolife) were spectrophotometrically adjusted to $10^{6} \mathrm{CFU} / \mathrm{mL}$, added to serial two-fold dilutions of extracts and compounds in a final volume of $100 \mu \mathrm{l}$ per well, and incubated for $18 \mathrm{~h}$ at $37^{\circ} \mathrm{C}$. In the case of fungi, an inoculum of approximately $2.5 \times$ $105 \mathrm{CFU} / \mathrm{mL}$ of spores/conidia was added to the wells and incubated at $35^{\circ} \mathrm{C}$ for $24 \mathrm{~h}$ (C. albicans) and $48 \mathrm{~h}$ (mold). The minimal inhibitory concentration (MIC) was defined as the lowest concentration that showed no visible bacterial growth (turbidity) in the wells. To determine the minimum bactericidal concentration (MBC), aliquots were taken from the wells corresponding to MIC, 2xMIC and 4xMIC and plated on MHA plates. After incubation at $37^{\circ} \mathrm{C}$ for $18 \mathrm{~h}$, the $\mathrm{MBC}$ value was determined as the lowest concentration causing $\sim 99.9 \%$ killing of the starting inoculum.

For fungi, aliquots from the wells were plated on SDA and incubated for 24 and $48 \mathrm{~h}$ at $35^{\circ} \mathrm{C}$. After counting colonies, $\mathrm{MIC}_{50}$ and $\mathrm{MIC}_{90}$ endpoints were recorded as the lowest concentrations that inhibited $50 \%$ and $90 \%$ of the fungal growth compared to the control. All tests were performed in triplicate.

\subsection{Antiproliferative Activity}

3.5.1. Antiproliferative Activity of Onion Extracts and Quercetin Conjugates

The antiproliferative assay was performed in the same way and with the same cancer cells (cervical cancer cell line-HeLa, human colon cancer cell line-HCT116 and human 
osteosarcoma cell line-U2OS) as described by Fredotović et al. [6], to compare the results obtained for onion bulb extracts with those obtained for onion waste extracts. The cells were a gift from the laboratory of Janoš Terzić at the School of Medicine, University of Split. Cells were grown in a $\mathrm{CO}_{2}$ incubator at $37{ }^{\circ} \mathrm{C}$ and $5 \% \mathrm{CO}_{2}$ until they reached $80 \%$ confluency. They were then seeded in 96-well plates (approximately 5000 cells per well) and treated with serial dilutions of the extracts. The plates were left in the incubator for $48 \mathrm{~h}$. Then, $20 \mu \mathrm{L}$ of MTS tetrazolium reagent (Promega) was added to each well, the 96-well plate was incubated at $37{ }^{\circ} \mathrm{C}$ and $5 \% \mathrm{CO}_{2}$ for another $3 \mathrm{~h}$, and then the absorbance was measured on a microplate reader (Bio-Tek, EL808). The $\mathrm{IC}_{50}$ value was calculated as the mean of three independent experiments using GraFit 6 data analysis software (Erithacus, East Grinstead, UK).

\subsubsection{Antiproliferative Activity of Onion Extracts after In Vitro Digestion}

The antiproliferation assay was performed in the same manner as described in Section 3.5.1., except that this time the cells were treated with digested peel extracts of onions. In vitro digestion was performed as described in previous studies [82,91]. Oral phase: $5 \mathrm{~g}$ of the onion extract was mixed with $3.5 \mathrm{~mL}$ of SSF (stimulated salivary fluid) and $0.5 \mathrm{~mL}$ of $\alpha$-amylase solution (1500 U/mL, Sigma-Aldrich, Saint Louis, MO, USA), followed by the addition of $25 \mathrm{~mL}$ of $0.3 \mathrm{M} \mathrm{CaCl}_{2}$ and $975 \mathrm{~mL}$ of water and shaken vigorously. Gastric phase: $10 \mathrm{~mL}$ of the previously treated sample was mixed with $7.5 \mathrm{~mL}$ of SGF (stimulated gastric fluid), $1.6 \mathrm{~mL}$ of pepsin solution (25000 U/mL, Sigma-Aldrich) prepared in the SGF solution, $5 \mathrm{~mL}$ of $0.3 \mathrm{M} \mathrm{CaCl}_{2}$ and $0.695 \mathrm{~mL}$ of water. $\mathrm{pH}$ was adjusted to 3.0 by adding $1 \mathrm{M} \mathrm{HCl}$. The mixture was left at $37{ }^{\circ} \mathrm{C}$ for $2 \mathrm{~h}$ in a shaking incubator (300 rpm). Intestinal phase: $11 \mathrm{~mL}$ of SIF (stimulated intestinal fluid), $5 \mathrm{~mL}$ of pancreatic solution prepared in SIF (800 U/mL, Sigma-Aldrich, Saint Louis, MO, USA), $2.5 \mathrm{~mL}$ of freshly prepared bile solution (160 mM, Sigma), $40 \mu \mathrm{L}$ of $0.3 \mathrm{M} \mathrm{CaCl}_{2}$ were added and the $\mathrm{pH}$ was adjusted to 7.0 by adding $1 \mathrm{M} \mathrm{NaOH}$. The mixture was made up to a final volume of $40 \mathrm{~mL}$ with water. The samples were incubated in a shaking incubator (300 rpm) at $37^{\circ} \mathrm{C}$ for an additional $2 \mathrm{~h}$. After completion of digestion, the samples were centrifuged at $4500 \times g$ for $10 \mathrm{~min}$ at $4{ }^{\circ} \mathrm{C}$, and the supernatant was collected and stored at $-80^{\circ} \mathrm{C}$ until the antiproliferation experiment. The composition of SSF, SGF, and SIF is shown in Table S1 (Supplementary Material).

\subsection{Statistical Analysis}

Experiments were performed in triplicate. All results were presented as mean $\pm \mathrm{SD}$. Statistical analysis was performed using GraphPad Prism Version 9. The mean values were compared using two-way ANOVA, followed by Tukey's and Dunnett's multiple comparison test for antiproliferative activity of waste extracts and HPLC analysis and Šídák's multiple comparison test for antiproliferative activity of quercetin conjugates and antioxidant analysis. Differences were considered significant at ${ }^{*} p<0.05,{ }^{* *} p<0.01,{ }^{* * *} p<$ 0.001 and $^{* * * *} p<0.0001$.

\section{Conclusions}

This was the first study of the chemical composition and biological activity of peel extracts from triploid onion Allium $\times$ cornutum (Ljutika). The results showed that the peel extracts of traditionally grown Dalmatian onions, $A . \times$ cornutum and two varieties of A. cepa, are rich in flavonols (the main antioxidant compounds) and possess antioxidant, antimicrobial and antiproliferative properties. Considering that a large amount of onion peel waste is generated annually, which is an increasing environmental and economic problem, new studies, including the present one, should provide insight into the possibility of their use as a source of biologically active phytochemicals that can be exploited in the pharmaceutical, cosmetic and food industries. However, further research is needed to identify other biologically active compounds present in onion wastes and the mechanism behind their biological activity. 
Supplementary Materials: The following are available online at https:/ / www.mdpi.com/article/10 .3390/plants10050832/s1, Figure S1: High-performance liquid chromatography (HPLC) of methanolic waste extracts of A. cepa red variety, Data S1: Statistical analysis of HPLC quantification of flavonols and anthocyanins, Data S2: Statistical analysis of antioxidant activity, Data S3: Statistical analysis of antiproliferative activity of onion waste extracts, Data S4: Statistical analysis of antiproliferative activity of quercetin conjugates, Data S5: Statistical analysis of antiproliferative activity of $A . \times$ cornutum after digestion, Data S6: Statistical analysis of antiproliferative activity of $A$. cepa (yellow variety) after digestion, Data S7: Statistical analysis of antiproliferative activity of $A$. cepa (red variety) after digestion, Data S8-1: Quality parameters of the optimized HPLC for flavonol quantification, Data S8-2: Stability data detection and quantification limits of 5 flavonoid standards analyzed by HPLC, Data S8-3: Stability data detection and quantification limits of four anthocyanins standard analysed by HPLC, Data S8-4: Quality parameters of the optimized HPLC for anthocyanin quantification, Table S1: Preparation of stock solutions of stimulated digestive fluids.

Author Contributions: Conceptualization, Ž.F.; methodology, Ž.F.; software, Ž.F.; validation, Ž.F.; formal analysis, Ž.F., M.N., A.M.; investigation, Ž.F., M.N., A.M., I.L., B.S. and D.B.; writing—original draft preparation, Ž.F.; writing-review and editing, Ž.F., J.P. and E.V. All authors have read and agreed to the published version of the manuscript.

Funding: This research received no external funding but institutional.

Institutional Review Board Statement: Not applicable.

Informed Consent Statement: Not applicable.

Data Availability Statement: All data is confirmed as original.

Conflicts of Interest: The authors declare no conflict of interest.

\section{References}

1. Fredotović, Ž.; Šamanić, I.; Weiss-Schneeweiss, H.; Kamenjarin, J.; Jang, T.-S.; Puizina, J. Triparental origin of triploid onion, Allium $\times$ cornutum (Clementi ex Visiani, 1842), as evidenced by molecular, phylogenetic and cytogenetic analyses. BMC Plant. Biol. 2014, 14, 24. [CrossRef]

2. Periodic Reporting for Period 1-FIBRACEP (“Valorization of European Onion Waste by-Products Into Dietary Fibre-Based Formula With Hypocholesterolemic, Hypoglycemic, and Antioxidant Effects") | Report Summary | FIBRACEP | H2020 | CORDIS | European Commis. Available online: https:// cordis.europa.eu/project/id/782061/it (accessed on 12 February 2021).

3. Pareek, S.; Sagar, N.A.; Sharma, S.; Yadav, V. Onion (Allium cepa L.). In Fruit and Vegetable Phytochemicals: Chemistry and Human Health, Volume II; Yahia, E.M., Ed.; John Wiley \& Sons Ltd: Hoboken, NJ, USA, 2018.

4. Block, E. The chemistry of garlic and onions. Sci. Am. 1985, 252, 114-119. [CrossRef] [PubMed]

5. Fredotović, Ž.; Šprung, M.; Soldo, B.; Ljubenkov, I.; Budić-Leto, I.; Bilušić, T.; Čikeš-Čulić, V.; Puizina, J. Chemical composition and biological activity of Allium cepa L. and Allium $\times$ cornutum (Clementi ex Visiani 1842) methanolic extracts. Molecules 2017, 22, 448. [CrossRef] [PubMed]

6. Fredotović, Ž.; Soldo, B.; Šprung, M.; Marijanović, Z.; Jerković, I.; Puizina, J. Comparison of organosulfur and amino acid composition between triploid onion allium cornutum Clementi ex Visiani, 1842, and common onion Allium cepa L., and evidences for antiproliferative activity of their extracts. Plants 2020, 9, 98. [CrossRef]

7. Arshad, M.S.; Sohaib, M.; Nadeem, M.; Saeed, F.; Imran, A.; Javed, A.; Amjad, Z.; Batool, S.M.; Yildiz, F. Status and trends of nutraceuticals from onion and onion by-products: A critical review. Cogent Food Agric. 2017, 3, 1280254. [CrossRef]

8. Le Marchand, L. Cancer preventive effects of flavonoids-A review. Biomed. Pharm. 2002, 56, 296-301. [CrossRef]

9. De Vries, J.H.M.; Hollman, P.C.H.; Meyboom, S.; Buysman, M.N.C.P.; Zock, P.L.; Van Staveren, W.A.; Katan, M.B. Plasma concentrations and urinary excretion of the antioxidant flavonols quercetin and kaempferol as biomarkers for dietary intake. Am. J. Clin. Nutr. 1998, 68, 60-65. [CrossRef]

10. Hollman, P.C.; van Trijp, J.M.; Buysman, M.N.C.; van der Gaag, M.S.; Mengelers, M.J.; de Vries, J.H.; Katan, M.B. Relative bioavailability of the antioxidant flavonoid quercetin from various foods in man. FEBS Lett. 1997, 418, 152-156. [CrossRef]

11. Hollman, P.C.H.; De Vries, J.H.M.; Van Leeuwen, S.D.; Mengelers, M.J.B.; Katan, M.B. Absorption of dietary quercetin glycosides and quercetin in healthy ileostomy volunteers. Am. J. Clin. Nutr. 1995, 62, 1276-1282. [CrossRef] [PubMed]

12. Felgines, C.; Texier, O.; Morand, C.; Manach, C.; Scalbert, A.; Régerat, F.; Rémésy, C. Bioavailability of the flavanone naringenin and its glycosides in rats. Am. J. Physiol. Gastrointest. Liver Physiol. 2000, 279, G1148-G1154. [CrossRef] [PubMed]

13. Nemeth, K.; Piskula, M.K. Food content, processing, absorption and metabolism of onion flavonoids. Crit. Rev. Food Sci. Nutr. 2007, 47, 397-409. [CrossRef]

14. Fredotović, Ž.; Puizina, J. Edible allium species: Chemical composition, biological activity and health effects. Ital. J. Food Sci. 2019, $31,19-39$. 
15. Halliwell, B.; Rafter, J.; Jenner, A. Health promotion by flavonoids, tocopherols, tocotrienols, and other phenols: Direct or indirect effects? Antioxidant or not? Am. J. Clin. Nutr. 2005, 81, 268S-276S. [CrossRef]

16. Pourzand, A.; Tajaddini, A.; Pirouzpanah, S.; Asghari-Jafarabadi, M.; Samadi, N.; Ostadrahimi, A.-R.; Sanaat, Z. Associations between Dietary Allium vegetables and risk of breast cancer: A hospital-based matched case-control study. J. Breast Cancer 2016, 19, 292. [CrossRef]

17. Nicastro, H.L.; Ross, S.A.; Milner, J.A. Garlic and onions: Their cancer prevention properties. Cancer Prev. Res. 2015, 8, 181-189. [CrossRef] [PubMed]

18. Tsai, T.-H.; Tsai, P.-J.; Ho, S.-C. Antioxidant and anti-inflammatory activities of several commonly used spices. J. Food Sci. 2005, 70, C93-C97. [CrossRef]

19. Upadhyay, R.K. Nutraceutical, pharmaceutical and therapeutic uses of Allium cepa: A review. Int. J. Green Pharm. 2016, 10, 46-64.

20. Ahiabor, C.; Gordon, A.; Ayittey, K.; Agyare, R. In vitro assessment of antibacterial activity of crude extracts of onion (Allium cepa L.) and shallot (Allium aescalonicum L.) on isolates of Escherichia coli (ATCC 25922), Staphylococcus aureus (ATCC 25923), and Salmonella typhi (ATCC 19430). Int. J. Appl. Res. 2016, 2, 1029-1032.

21. Bakri, I.M.; Douglas, C.W.I. Inhibitory effect of garlic extract on oral bacteria. Arch. Oral Biol. 2005, 50, 645-651. [CrossRef]

22. Ann, T.; Thakur, S.; Habib, R. Comparison of antimicrobial efficacy of green tea, garlic with lime, and sodium fluoride mouth rinses against Streptococcus mutans, Lactobacilli species, and Candida albicans in children: A randomized double-blind controlled clinical trial. Int. J. Clin. Pediatr. Dent. 2017, 10, 234-239.

23. Panche, A.N.; Diwan, A.D.; Chandra, S.R. Flavonoids: An overview. J. Nutr. Sci. 2016, 5, e47. [CrossRef]

24. Koca, I.; Tekguler, B.; Odabas, H.I. Comparison of the antioxidant properties of some onion and garlic cultivars grown in Turkey. In Proceedings of the Acta Horticulturae, International Society for Horticultural Science, Nigde, Turkey, 21-25 May 2015; Volume 1143, pp. 207-214.

25. Colina-Coca, C.; González-Peña, D.; de Ancos, B.; Sánchez-Moreno, C. Dietary onion ameliorates antioxidant defence, inflammatory response, and cardiovascular risk biomarkers in hypercholesterolemic Wistar rats. J. Funct. Foods 2017, 36, 300-309. [CrossRef]

26. Boyle, S.P.; Dobson, V.L.; Duthie, S.J.; Kyle, J.A.; Collins, A.R. Absorption and DNA protective effects of flavonoid glycosides from an onion meal. Eur. J. Nutr. 2000, 39, 213-223. [CrossRef]

27. Corzo-Martínez, M.; Corzo, N.; Villamiel, M. Biological properties of onions and garlic. Trends Food Sci. Technol. 2007, 18, 609-625. [CrossRef]

28. Škerget, M.; Majheniè, L.; Bezjak, M.; Knez, D. Antioxidant, Radical Scavenging and Antimicrobial Activities of Red Onion (Allium cepa L) Skin and Edible Part. Extracts; Hrvatsko Društvo Kemijskih Inženjera i Tehnologa: Zagreb, Croatia, 2009 ; Volume 23.

29. Ramos, F.A.; Takaishi, Y.; Shirotori, M.; Kawaguchi, Y.; Tsuchiya, K.; Shibata, H.; Higuti, T.; Tadokoro, T.; Takeuchi, M. Antibacterial and antioxidant activities of quercetin oxidation products from yellow onion (Allium cepa) skin. J. Agric. Food Chem. 2006, 54, 3551-3557. [CrossRef] [PubMed]

30. Bianchini, F.; Vainio, H. Allium vegetables and organosulfur compounds: Do they help prevent cancer? Env. Health Perspect. 2001, 109, 893-902. [CrossRef] [PubMed]

31. Turati, F.; Guercio, V.; Pelucchi, C.; La Vecchia, C.; Galeone, C. Colorectal cancer and adenomatous polyps in relation to allium vegetables intake: A meta-analysis of observational studies. Mol. Nutr. Food Res. 2014, 58, 1907-1914. [CrossRef]

32. Roldán-Marín, E.; Krath, B.N.; Poulsen, M.; Binderup, M.L.; Nielsen, T.H.; Hansen, M.; Barri, T.; Langkilde, S.; Pilar Cano, M.; Sánchez-Moreno, C.; et al. Effects of an onion by-product on bioactivity and safety markers in healthy rats. Br. J. Nutr. 2009, 102, 1574-1582. [CrossRef]

33. Pan, Y.; Zheng, Y.M.; Ho, W.S. Effect of quercetin glucosides from Allium extracts on HepG2, PC-3 and HT-29 cancer cell lines. Oncol. Lett. 2018, 15, 4657-4661. [CrossRef]

34. Chang, Y.C.; Tsai, M.H.; Sheu, W.H.H.; Hsieh, S.C.; Chiang, A.N. The therapeutic potential and mechanisms of action of quercetin in relation to lipopolysaccharide-induced sepsis in vitro and in vivo. PLoS ONE 2013, 8, e80744. [CrossRef]

35. Tanaka, T.; Makita, H.; Ohnishi, M.; Mori, H.; Satoh, K.; Hara, A.; Sumida, T.; Fukutani, K.; Tanaka, T.; Ogawa, H. Chemoprevention of 4-nitroquinoline 1-oxide-induced oral carcinogenesis in rats by flavonoids diosmin and hesperidin, each alone and in combination. Cancer Res. 1997, 57, 246-252. [PubMed]

36. Makita, H.; Tanaka, T.; Fujitsuka, H.; Tatematsu, N.; Satoh, K.; Hara, A.; Mori, H. Chemoprevention of 4-nitroquinoline 1-oxideinduced rat oral carcinogenesis by the dietary flavonoids chalcone, 2-hydroxychalcone, and quercetin. Cancer Res. 1996, 56, 4904-4909. [PubMed]

37. Tanaka, T.; Makita, H.; Kawabata, K.; Mori, H.; Kakumoto, M.; Satoh, K.; Hara, A.; Sumida, T.; Tanaka, T.; Ogawa, H. Chemoprevention of azoxymethane-induced rat colon carcinogenesis by the naturally occurring flavonoids, diosmin and hesperidin. Carcinogenesis 1997, 18, 957-965. [CrossRef]

38. Sundaram, S.G.; Milner, J.A. Diallyl disulfide induces apoptosis of human colon tumor cells. Carcinogenesis 1996, 17, 669-673. [CrossRef] [PubMed]

39. Dhawan, A.; Bajpayee, M. (Eds.) Genotoxicity assessment. In Methods in Molecular Biology; Humana Press: Totowa, NJ, USA, 2013; Volume 1044, ISBN 978-1-62703-528-6.

40. Filomeni, G.; Aquilano, K.; Rotilio, G.; Ciriolo, M.R. Reactive oxygen species-dependent c-Jun NH2-terminal kinase/c-Jun signaling cascade mediates neuroblastoma cell death induced by diallyl disulfide. Cancer Res. 2003, 63, 5940-5949. [PubMed] 
41. Yang, C.S.; Chhabra, S.K.; Hong, J.-Y.; Smith, T.J. Mechanisms of inhibition of chemical toxicity and carcinogenesis by diallyl sulfide (DAS) and related compounds from garlic. J. Nutr. 2001, 131, 1041S-1045S. [CrossRef] [PubMed]

42. Kwon, K.-B.; Yoo, S.-J.; Ryu, D.-G.; Yang, J.-Y.; Rho, H.-W.; Kim, J.-S.; Park, J.-W.; Kim, H.-R.; Park, B.-H. Induction of apoptosis by diallyl disulfide through activation of caspase-3 in human leukemia HL-60 cells. Biochem. Pharm. 2002, 63, 41-47. [CrossRef]

43. Sankaranarayanan, R.; Varghese, C.; Duffy, S.W.; Padmakumary, G.; Day, N.E.; Nair, M.K. A case-control study of diet and lung cancer in Kerala, south India. Int. J. Cancer 1994, 58, 644-649. [CrossRef]

44. Gao, C.M.; Takezaki, T.; Ding, J.H.; Li, M.S.; Tajima, K. Protective effect of allium vegetables against both esophageal and stomach cancer: A simultaneous case-referent study of a high-epidemic area in Jiangsu Province, China. Jpn. J. Cancer Res. 1999, 90, 614-621. [CrossRef]

45. Zhou, Y.; Zhuang, W.; Hu, W.; Liu, G.; Wu, T.; Wu, X. Consumption of Large amounts of allium vegetables reduces risk for gastric cancer in a meta-analysis. Gastroenterology 2011, 141, 80-89. [CrossRef]

46. González, C.A.; Pera, G.; Agudo, A.; Bueno-de-Mesquita, H.B.; Ceroti, M.; Boeing, H.; Schulz, M.; Del Giudice, G.; Plebani, M.; Carneiro, F.; et al. Fruit and vegetable intake and the risk of stomach and oesophagus adenocarcinoma in the European Prospective Investigation into cancer and nutrition (EPIC-EURGAST). Int. J. Cancer 2006, 118, 2559-2566. [CrossRef] [PubMed]

47. Hu, J.; La Vecchia, C.; Negri, E.; Chatenoud, L.; Bosetti, C.; Jia, X.; Liu, R.; Huang, G.; Bi, D.; Wang, C. Diet and brain cancer in adults: A case-control study in northeast China. Int. J. Cancer 1999, 81, 20-23. [CrossRef]

48. Kim, J.; Kim, J.S.; Park, E. Cytotoxic and anti-inflammatory effects of onion peel extract on lipopolysaccharide stimulated human colon carcinoma cells. Food Chem. Toxicol. 2013, 62, 199-204. [CrossRef] [PubMed]

49. Boyer, J.; Brown, D.; Rui, H.L. Uptake of quercetin and quercetin 3-glucoside from whole onion and apple peel extracts by Caco-2 cell monolayers. J. Agric. Food Chem. 2004, 52, 7172-7179. [CrossRef]

50. Elberry, A.A.; Mufti, S.; Al-Maghrabi, J.; Abdel Sattar, E.; Ghareib, S.A.; Mosli, H.A.; Gabr, S.A. Immunomodulatory effect of red onion (Allium cepa Linn) scale extract on experimentally induced atypical prostatic hyperplasia in wistar rats. Mediat. Inflamm. 2014, 2014, 13. [CrossRef] [PubMed]

51. Caridi, D.; Trenerry, V.C.; Rochfort, S.; Duong, S.; Laugher, D.; Jones, R. Profiling and quantifying quercetin glucosides in onion (Allium cepa L.) varieties using capillary zone electrophoresis and high performance liquid chromatography. Food Chem. 2007, 105, 691-699. [CrossRef]

52. Rodrigues, A.S.; Almeida, D.P.F.; Simal-Gándara, J.; Pérez-Gregorio, M. Onions: A source of flavonoids. In Flavonoids—From Biosynthesis to Human Health; Justino, G.C., Ed.; IntechOpen: London, UK, 2017.

53. Nile, A.; Nile, S.H.; Kim, D.H.; Keum, Y.S.; Seok, P.G.; Sharma, K. Valorization of onion solid waste and their flavonols for assessment of cytotoxicity, enzyme inhibitory and antioxidant activities. Food Chem. Toxicol. 2018, 119, 281-289. [CrossRef]

54. Nile, S.H.; Nile, A.S.; Keum, Y.S.; Sharma, K. Utilization of quercetin and quercetin glycosides from onion (Allium cepa L.) solid waste as an antioxidant, urease and xanthine oxidase inhibitors. Food Chem. 2017, 235, 119-126. [CrossRef]

55. Benítez, V.; Mollá, E.; Martín-Cabrejas, M.A.; Aguilera, Y.; López-Andréu, F.J.; Cools, K.; Terry, L.A.; Esteban, R.M. Characterization of industrial onion wastes (Allium cepa L.): Dietary fibre and bioactive compounds. Plant. Foods Hum. Nutr. 2011, 66, 48-57. [CrossRef]

56. Albishi, T.; John, J.A.; Al-Khalifa, A.S.; Shahidi, F. Antioxidant, anti-inflammatory and DNA scission inhibitory activities of phenolic compounds in selected onion and potato varieties. J. Funct. Foods 2013, 5, 930-939. [CrossRef]

57. Gennaro, L.; Leonardi, C.; Esposito, F.; Salucci, M.; Maiani, G.; Quaglia, G.; Fogliano, V. Flavonoid and carbohydrate contents in Tropea red onions: Effects of homelike peeling and storage. J. Agric. Food Chem. 2002, 50, 1904-1910. [CrossRef]

58. Sharma, K.; Mahato, N.; Nile, S.H.; Lee, E.T.; Lee, Y.R. Economical and environmentally-friendly approaches for usage of onion (Allium cepa L.) waste. Food Funct. 2016, 7, 3354-3369. [CrossRef] [PubMed]

59. Sharma, K.; Assefa, A.D.; Kim, S.; Ko, E.Y.; Lee, E.T.; Park, S.W. Evaluation of total phenolics, flavonoids and antioxidant activity of 18 Korean onion cultivars: A comparative study. J. Sci. Food Agric. 2014, 94, 1521-1529. [CrossRef] [PubMed]

60. Verzelloni, E.; Tagliazucchi, D.; Conte, A. Relationship between the antioxidant properties and the phenolic and flavonoid content in traditional balsamic vinegar. Food Chem. 2007, 105, 564-571. [CrossRef]

61. Lampe, J.W. Health effects of vegetables and fruit: Assessing mechanisms of action in human experimental studies. Am. J. Clin. Nutr. Am. Soc. Nutr. 1999, 70, 475s-490s. [CrossRef]

62. Kim, S.M.; Kubota, K.; Kobayashi, A. Antioxidative activity of sulfur-containing flavor compounds in garlic. Biosci. Biotechnol. Biochem. 1997, 61, 1482-1485. [CrossRef]

63. Chen, M.; Meng, H.; Zhao, Y.; Chen, F.; Yu, S. Antioxidant and in vitro anticancer activities of phenolics isolated from sugar beet molasses. BMC Complement. Altern. Med. 2015, 15, 313. [CrossRef] [PubMed]

64. Lee, K.A.; Kim, K.T.; Kim, H.J.; Chung, M.S.; Chang, P.S.; Park, H.; Pai, H.D. Antioxidant activities of onion (Allium cepa L.) peel extracts produced by ethanol, hot water, and subcritical water extraction. Food Sci. Biotechnol. 2014, 23, 615-621. [CrossRef]

65. Nuutila, A.M.; Puupponen-Pimiä, R.; Aarni, M.; Oksman-Caldentey, K.M. Comparison of antioxidant activities of onion and garlic extracts by inhibition of lipid peroxidation and radical scavenging activity. Food Chem. 2003, 81, 485-493. [CrossRef]

66. Yin, M.C.; Tsao, S.M. Inhibitory effect of seven Allium plants upon three Aspergillus species. Int. J. Food Microbiol. 1999, 49, 49-56. [CrossRef]

67. Rauha, J.P.; Remes, S.; Heinonen, M.; Hopia, A.; Kähkönen, M.; Kujala, T.; Pihlaja, K.; Vuorela, H.; Vuorela, P. Antimicrobial effects of Finnish plant extracts containing flavonoids and other phenolic compounds. Int. J. Food Microbiol. 2000, 56, 3-12. [CrossRef] 
68. Santas, J.; Almajano, M.P.; Carbó, R. Antimicrobial and antioxidant activity of crude onion (Allium cepa L.) extracts. Int. J. Food Sci. Technol. 2010, 45, 403-409. [CrossRef]

69. Lee, K.A.; Kim, K.T.; Nah, S.Y.; Chung, M.S.; Cho, S.W.; Paik, H.D. Antimicrobial and antioxidative effects of onion peel extracted by the subcritical water. Food Sci. Biotechnol. 2011, 20, 543-548. [CrossRef]

70. Xiao, J. Dietary flavonoid aglycones and their glycosides: Which show better biological significance? Crit. Rev. Food Sci. Nutr. 2017, 57, 1874-1905. [CrossRef]

71. Xu, H.X.; Lee, S.F. Activity of plant flavonoids against antibiotic-resistant bacteria. Phyther. Res. 2001, 15, 39-43. [CrossRef]

72. Murayyan, A.I.; Manohar, C.M.; Hayward, G.; Neethirajan, S. Antiproliferative activity of Ontario grown onions against colorectal adenocarcinoma cells. Food Res. Int. 2017, 96, 12-18. [CrossRef]

73. Xu, X.Y.; Song, G.Q.; Yu, Y.Q.; Ma, H.Y.; Ma, L.; Jin, Y.N. Apoptosis and G2/M arrest induced by Allium ursinum (ramson) watery extract in an AGS gastric cancer cell line. OncoTargets Ther. 2013, 6, 779-783. [CrossRef]

74. Li, W.; Liu, M.; Xu, Y.F.; Feng, Y.; Che, J.P.; Wang, G.C.; Zheng, J.H. Combination of quercetin and hyperoside has anticancer effects on renal cancer cells through inhibition of oncogenic microRNA-27a. Oncol. Rep. 2014, 31, 117-124. [CrossRef]

75. Mutoh, M.; Takahashi, M.; Fukuda, K.; Komatsu, H.; Enya, T.; Matsushima-Hibiya, Y.; Mutoh, H.; Sugimura, T.; Wakabayashi, K. Suppression by flavonoids of cyclooxygenase-2 promoter-dependent transcriptional activity in colon cancer cells: Structureactivity relationship. Jpn. J. Cancer Res. 2000, 91, 686-691. [CrossRef]

76. Chang, W.S.; Lee, Y.J.; Lu, F.J.; Chiang, H.C. Inhibitory effects of flavonoids on xanthine oxidase. Anticancer Res. 1993, 13, 2165-2170.

77. Kothari, D.; Lee, W.-D.; Kim, S.-K. Allium flavonols: Health benefits, molecular targets, and bioavailability. Antioxidants 2020, 9 , 888. [CrossRef]

78. Hur, S.J.; Lee, S.J.; Kim, D.H.; Chun, S.C.; Lee, S.K. Onion extract structural changes during in vitro digestion and its potential antioxidant effect on brain lipids obtained from low-and high-fat-fed mice. Free Radic. Res. 2013, 47, 1009-1015. [CrossRef]

79. Bermúdez-Soto, M.J.; Tomás-Barberán, F.A.; García-Conesa, M.T. Stability of polyphenols in chokeberry (Aronia melanocarpa) subjected to in vitro gastric and pancreatic digestion. Food Chem. 2007, 102, 865-874. [CrossRef]

80. Lee, S.Y.; Lee, S.J.; Yim, D.G.; Hur, S.J. Changes in the content and bioavailability of onion quercetin and grape resveratrol during in vitro human digestion. Foods 2020, 9, 694. [CrossRef]

81. Zivkovic, J.; Savikin, K.; Stanisavljevic, N.; Zdunic, G.; Stanojkovic, T.; Samardzic, J. Chemical composition and antiproliferative potential of dried wild apple and pear tea before and after in vitro simulated digestion. J. Serb. Chem. Soc. 2018, 83, 1315-1326. [CrossRef]

82. Stanisavljević, N.; Soković Bajić, S.; Jovanović, Ž.; Matić, I.; Tolinački, M.; Popović, D.; Popović, N.; Terzić-Vidojević, A.; Golić, N.; Beškoski, V.; et al. Antioxidant and antiproliferative activity of allium ursinum and their associated microbiota during simulated in vitro digestion in the presence of food matrix. Front. Microbiol. 2020, 11, 3043. [CrossRef]

83. Murota, K.; Terao, J. Antioxidative flavonoid quercetin: Implication of its intestinal absorption and metabolism. Arch. Biochem. Biophys. 2003, 417, 12-17. [CrossRef]

84. Su, M.S.; Chien, P.J. Antioxidant activity, anthocyanins, and phenolics of rabbiteye blueberry (Vaccinium ashei) fluid products as affected by fermentation. Food Chem. 2007, 104, 182-187. [CrossRef]

85. Nazlić, M.; Kremer, D.; Grubešić, R.J.; Soldo, B.; Vuko, E.; Stabentheiner, E.; Ballian, D.; Bogunić, F.; Dunkić, V. Endemic Veronica saturejoides Vis. ssp. saturejoides-Chemical composition and antioxidant activity of free volatile compounds. Plants 2020, 9, 1646. [CrossRef]

86. Yen, G.C.; Pin-Der, D. Scavenging effect of methanolic extracts of peanut hulls on free-radical and active-oxygen species. J. Agric. Food Chem. 1994, 42, 629-632. [CrossRef]

87. EUCAST. Breakpoint Tables for Interpretation of MICs and Zone Diameters. Version 10.0. 2020. EUCAST, 2020. Available online: https: / / www.eucast.org (accessed on 24 February 2021).

88. EUCAST. Method for the Determination of Broth Dilution Minimum Inhibitory Concentrations of Antifungal Agents for Yeasts. EUCAST Definitive Document E. Def 7.3.2.. 2020. Available online: https://www.eucast.org/astoffungi/ methodsinantifungalsusceptibilitytesting/susceptibility_testing_of_yeasts (accessed on 24 February 2021).

89. EUCAST. Method for the Determination of Broth Dilution Minimum Inhibitory Concentrations of Antifungal Agents for Conidia Forming Moulds EUCAST Definitive Document E. Def 9.3.2.. 2020. Available online: https://www.eucast.org/astoffungi/ methodsinantifungalsusceptibilitytesting/ast_of_moulds (accessed on 24 February 2021).

90. Bazina, L.; Maravić, A.; Krce, L.; Soldo, B.; Odžak, R.; Popović, V.B.; Aviani, I.; Primožič, I.; Šprung, M. Discovery of novel quaternary ammonium compounds based on quinuclidine-3-ol as new potential antimicrobial candidates. Eur. J. Med. Chem. 2019, 163, 626-635. [CrossRef] [PubMed]

91. Minekus, M.; Alminger, M.; Alvito, P.; Ballance, S.; Bohn, T.; Bourlieu, C.; Carrière, F.; Boutrou, R.; Corredig, M.; Dupont, D.; et al. A standardised static in vitro digestion method suitable for food-an international consensus. Food Funct. 2014, 5, 1113-1124. [CrossRef] 